\title{
Edmund Przekop
}

Tendencje ekumeniczne $\mathrm{w}$ wypowiedziach przedstawicieli Kościołów wschodnich na I Soborze Watykańskim

Prawo Kanoniczne : kwartalnik prawno-historyczny 15/3-4, 61-80

1972

Artykuł został zdigitalizowany i opracowany do udostępnienia w internecie przez Muzeum Historii Polski w ramach prac podejmowanych na rzecz zapewnienia otwartego, powszechnego i trwałego dostępu do polskiego dorobku naukowego i kulturalnego. Artykuł jest umieszczony w kolekcji cyfrowej bazhum.muzhp.pl, gromadzącej zawartość polskich czasopism humanistycznych i społecznych.

Tekst jest udostępniony do wykorzystania w ramach dozwolonego użytku. 
KS. EDMUND PRZEKOP

\section{TENDENCJE EKUMENICZNE W WYPOWIEDZIACH PRZEDSTAWICIELI KOSCIOLÓW WSCHODNICH NA I SOBORZE WATYKANSKIM}

'T r eś ć: Wstẹp. I. Wypowiedzi trzech patriarchów wschodnich. 1. Patriarcha chaldejski - Józef Audo. - 2. Patriarcha melchicki Grzegorz Jussef z Antiochii. - 3. Patriarcha armeński - Antoni Piotr IX Hassun. II. Dalsze ekumeniczne wystąpienia Ojcow soborowych. III. Sprzeciwy wobec ekumenicznych żądań Wschodu. IV. Zakończenie Soboru.

\section{Wstęp}

Zainteresowania II Soborem Watykańskim, który według ogólnego mniemania, miał w pewnym stopniu kontynuować nie dokończone - szczególnie w eklezjologii - dzieło Soboru I Watykańskiego, kierują w coraz większym stopniu uwagę teologów na obrady i wyniki tegoż ostatniego. Wielu badaczy nadto zauważa, że przebieg obrad i uchwały Vaticanum I są dotąd przedstawiane przeważnie w sposób uproszczony, nierzadko jednostronnie, co w konsekwencji prowadzi do powstania nieporozumień. Wysunięto nawet twierdzenie, że badania I Soboru Watykańskiego znajdują się zaledwie w stadium początkowym ${ }^{1}$. Tezę tę potwierdzają liczne studia publikowane $w$ ostatnich latach na temat Vaticanum I. Celem ich jest pełniejsze ukazanie przebiegu i wynikow tego Soboru oraz sprawiedliwsza ocena poglądów reprezentowanych na różne kwestie przez jego uczestników.

W polskiej literaturze teologicznej odczuwa się dziś - z racji rozwijającego się na szeroką skalę ekumenizmu - wyraźną potrzebę studium na temat udziału przedstawicieli Katolickich Kościołów wschodnich w obradach Vaticanum I.

${ }^{1} \mathrm{H} . \mathrm{B} \circ \mathrm{gacki}$, Teoria soboru powszechnego $w$ przygotowaniu $i$ obradach I Soboru Watykańskiego, Warszawa 1965 (ATK), s. 49-50; Por. W. Kasper, Primat und Eviskopat nach dem Vatikanum I., Tübinger Theologische Quartalschrift 142 (1962) 47-48; Dowodem szczególnie ożywionych obecnie zainteresowań dziejami I Soboru Watykań. skiego są drobiazgowe studia poświęcone udziałowi w Soborze poszczególnych grup biskupów. O. Al b e rti w swoim dziele: I vescovi sardi al Concilio Vaticano $I$, Roma 1963, poświęca aż 380 stron na omówienie uczestnictwa w Soborze tylko trzech biskupów sardyńskich, zresztą nie wyróżniających się wśród grona Ojców Soboru swą działalnością. 
Clem niniejszego artykułu jest wypełnić właśnie tę lukę; przede wszystkim zaś odkryć ducha eirumenizmu w wypowiedziach hierarchớw wschodnich na I Soborze Watykańskim, dla których dążność do przezwyciężenia podziału między chrześcijańskim Wschodem a Zachodem byla sprawą niemalej wagi. Dalo się to mocno odczuć jeszcze w okresie przygotowawczym do Soboru, gdy w 1866 r. kard. B a r nabo, prefekt Kongregacji Rozkrzewiania Wiary, wystosował 22 II list do niektórych biskupów obrządków wschodnich, zwłaszcza greckiego, przedstawiając w nim prośbę papieża, by zechcieli zaproponować tematy, ktöre ich zdaniem winny stać się przedmiotem soborowych obrad ${ }^{2}$. Wśród nadesłanych odpowiedzi (znanych jest tylko 9) ${ }^{3}$ znajdują się dwa charakterystyczne w naszej kwestii głosy, domagające się zaproszenia na Sobór także odłączonych hierarchów wschodnich. Myśl tę wysunął bardzo wyraźnie ormiański patriarcha Cylicji A. Hassun. Uważał bowiem, że takie zaproszenie jest niezbędne, jeżeli Sobór ma rzeczywiście posunąć naprzód sprawe zjednoczenia z Kościołem katolcikim odłączonych Kościołów wschodnich. W tym celu należy, zdaniem tego patriarchy, zaprosić do uczestnictwa w Soborze cały episkopat wschodni, ponieważ zaproszenie samych patriarchów i najwybitniejszych biskupów może wywołać wiele nickorzystnych reakcji wywołanych względami osobistymi ${ }^{4}$. Identyczne życzenie wyraził równiez biskup greckiego obrządku z Nagyvarad J. P a p p-S zi1 á g y i ${ }^{5}$. Natomiast żaden $\mathrm{z}$ biskupów obrządków wschodnich nie postulował dogmatycznego określenia prymatu papieskiego, ogół za to domagał się unikania w obradach soborowych tego wszystkiego, co mogłoby utrudniać powrót do Kościoła odłączonych chrześcijan wschodnich.

Mając powyższe na uwadze artykuz stawia problem, czy istotnie troska o jedność Wschodu z Zachodem byla obecna w jakiejś mierze także w obradach Vaticanum I. W tej kwestii przeważa bowiem opinia autorów, że tenże Sobór, obradujący zresztą w napiętej atmosferze, niczego nie dokonał na polu zbliżenia poszczególnych wspólnot chrześcijańskich, innymi słowy, że I Sobór Watykański nie był w ogóle zgromadzeniem elsumenicznym.

Badając ten problem warto juz na samym początku zaznaczyć, że jeżeli słowa "ekumeniczny" używa się na oznaczenie soborów

2 J. IM a $\mathrm{n}$ i, Sacrorim Conciliorum nova et amplissima collectio, wyd. L. Petit-J. B. Martin, t. 49-53, Arnhem-Leipzig 1923-1927 (skrót: Mansi), t. 49, kol. 179-182; O. A 1 b e r ti, dz. cyt., s. 221-230; C. Butler, Das I. Vatikanische Konzil, Nünchen ${ }^{2}$ 1961, s. 70-71; A ubert R., Vatican I, Paris 1964, s. 41-44; H. B o ga c is i, dz. cyt., s. 146 , przyp. 43 .

I I a n s i $49,181-202$.

4 Tamże, 184 C-185 A; H. B o g a c k i, dz. cyt., s. 150.

5 M a n s i 49, 196 D-197 A. Jego zdaniem jest konieczna podczas Soboru również obecność wysłanników władców świeckich. 
całego Kościola, to $\mathrm{z}$ całą pewnością Vaticanum I był soborem ekumenicznym, zwłaszcza że liczba jego uczestników - czynnik, którego nie można nie doceniać przy określaniu ekumeniczności ${ }^{6}$ osiągnęla nie notowana dotąd wysokośc. Według bowiem końcowego wykazu akt soborowych na 1084 uprawnionych do głosowania na Sobór przybyło 835 7. Po raz pierwszy w historii Kościoła stawili się na Sobór biskupi z 5 części świata; po raz pierwszy od czasów Soboru Florenckiego przybyli do Rzymu również przedstawiciele róźnych obrządków unijnych.

Jeżeli jednak ekumenizm ma oznaczać to, co pod tym pojęciem rozumie się $\mathrm{w}$ dzisiejszej teologii, mianowicie otwartość na sytuację braci odłączonych oraz gotowość do szczerego z nimi dialogu w kierunku zjednoczenia poszczególnych wspólnot chrześcijańskich, to nistety nie wydaje się, aby tak pojmowany ekumenizm był cechą charakteryzującą I Sobór Watykański, a tym bardziej uchwaloną na nim konstytucję dogmatyczną Pastor aeternus. Zresztą od samego początku nie należało zbyt wiele oczekiwać pod tym względem od uczestników Soboru, a to z tej prostej przyczyny, że teologia katolicka XIX w. jeszcze z pewną rezerwą odnosiła się do ruchu ekumenicznego. Fakt natomiast, że odłączone Kościoły wschodnie zostały imiennie zaproszone do udziału w obradach soborowych, tylko $z$ trudem może posłużyć za argument przeciwny, gdyż pismo papieskie wydane 22 IX $1868 \mathrm{r}$. do odłączonych biskupów wschodnich, antydatowane na dzień 8 IX t. r. ${ }^{8}$, zawierało raczej upomnienie do wyrzeczenia się ,,szatańskiego dzieła" schizmy, aniżeli rze“zywiste zaproszenie na Sobór. Wprawdzie list papieski powołuje się na pisma Ojców wschodnich i przykład uczestniczenia Greków w II Soborze Lyońskim, lecz właściwie sprowadza się on do wezwania odlączonych Kościolów wschodnich do jedności ze Stolicą Apostolską ${ }^{9}$. Również ze strony adresatów nie doszło do jakiejkolwiek

${ }^{6}$ Nie kwestionuje się tu wcale, że na pojęcie ekumenizmu składają się jeszcze inne czynnilri. Na ten temat por. H. J. M a r g u 11, Die ökumenischen Konzile der Christenheit, Stuttgart 1961; J. B e u m e r, Okumenische Tendenzen auf dem Ersten Vatikanum, w: Theologie und Philosophie, 45 (1970) 390.

7 M a n s i 52, 1062-1082. Wykaz ten obejmuje wszystkich biskupów, którzy brali udział $w$ obradach $w$ jakimkolwiels czasie, niekoniecznie na rozpoczęcie czy zalkończenie Soboru. Na tej podstawie $\mathrm{H}$. B o ga ck i W swoim atrykule $W$ stulecie I Soboru Watykańskiego ("Collectanea Theologica”, 40 (1970), z. 4, s. 53 n.) podaje, że 8 XII 1869 r. zebrało się w auli soborowej 774 uczestników.

8 M a n s i $49,1255-1260$.

9 Pismo papieskie nawołuje do powrotu do jedności, lecz nie wspomina ani jednym słowem o współwinie łacinników za schizmę. Por. O. Karreir, Das ökumenische Konzil in der römisch-katholischen Kirche der Gegenwart, w dziele zbiorowym: H. J. M a r g u 11, Die okumenischen Konzile der Christenheit, s. 243; MI. L e h ma n n, Das I. Vatikanische Konzil und die getrennte Ostkirche, Theologisch-praktische Quartalschrift 110 (1962) 287-301; HI. B o g a cki, dz. cyt., s. 195. 
pozytywnej reakcji 10. Dyskusje na początku Soboru wykazywały ten sam niekorzystny obraz, gdyż zaledwie przy pojedynczych tylko okazjach darzono uwagą protestantow, sytuacja których - po ogłoszeniu dogmatu o papieskiej nieomylności - ulegla dalszemu pogorszeniu ${ }^{11}$. Dopiero wystąiennia wschodnich biskupów różnych unijnych obrządków wniosły - nie naruszając w niczym samej definicji - zdecydowany rys ekumeniczny do rozpraw soborowych.

$\mathrm{W}$ poniżsych wywodach będziemy postępowali właśnie śladem tego ekumenicznego rysu czy też przynajmniej objawiających sie w nim elrumenicznych tendencji. Totez kompletność danych nie jest tutaj wcale zamierzona, bo też i niepotrzebna dla przebadania tego zagadnienia.

\section{Wypowiedzi trzech patriarchów wschodnich}

Wśród biskupów unijnych obrządków wschodnich przybyłych na Sobór do Rzymu zaznaczył się podział na 2 grupy: pierwsza z krajów naddunajskiej monarchii (Węgry, Siedmiogród), różniąca się językiem liturgicznym (ruski, grecki i rumuński), druga — małoazjatycka $z$ terenów Turcji i graniczącej z nią Persji. Ojcowie wschodni przynależący do drugiej grupy znajdowali się pod przewodnictwem swoich patriarchów: melchickiego, chaldejskiego, syryjskiego i armeńskiego. Na Sobór nie przybyl jedynie patriarcha maronicki, chociaż na przesłane mu zaproszenie odpowiedział po-

\footnotetext{
10 Niewątpliwie na odstraszenie odlączonych chrześcijan od myśli powrotu i kontaktu z Rzymem wplynęly w dużej mierze pogloski, że Sobór ma określić nieomylność papieską. Głośna polemika, prowadzona w owym czasie wokół nieomylności papieskiej potęgowała wśród chrzescijan odłączonych żywe obawy przed absolutyzmem papieża i nie sprzyjała pozytywnej analizie listu papieskiego wydanego do nich z okazji zapowiedzianego Soboru. Do tego atmosfera wzajemnej nieufności również uniemożliwiała podjęcie szczerych wysiłków w kierunku poszukiwania dróg zjednoczenia (Por. $\mathbf{F}$. de W y els, Le Concile du Vatican et l'union, Irénikon 6 (1929) 366-396, 488-516; J. C o n g a r, Les conciles dans la vie de l'Église, w dziele: Sainte Église, Paris 1963, 320-322.

11 Oczywiście istnieją wyjątki, jak np. glośne wystąpienie bpa Józefa Jerzego Strossmayera z 22 III 1870 r. (M a ins i 51, 72-77), w której zaatakowal zawarte $w$ schemacie stwierdzenie, że protestantyzm jest źródłem wszelkiego zła i błędów po Soborze Trydenckim. Strossmayer napiętnowal nie tylko powierzchowność takiej syntezy, lecz stwierdził, że wśród protestantów żyje wielu ludzi szczerze oddanych Chrystusowi i trwających $w$ dobrej wierze (bona fides) $w$ swej religii (M a n si 51, 74-75). Podobne zastrzeżenie wysunął także bp Meignan (M a ns i, 51, 81). Charakterystyczna jest także uwaga bpa $z$ Plymouth Williama Voughan: „Haec enim definitio multos catholicos certissime a sancta sede alienatura est, immo in schisma apertum propellet. Protestantibus ecclesiae propinquantibus novas quaestiones et difficultates creabit" (M a n s i 51, 1003). Por. U. $\mathrm{Ne} \mathrm{m} \mathrm{b}$ a $\mathrm{ch}$, Die Stellung der evangelischen Kirche und ihrer Presse zum Ersten Vatikanischen Konzil, Zurich 1962; B e u m e r, art. cyt., s. 391, przyp. 10.
} 
zytywnie 12. Zjawil się za tu w auli soborowej przedstawiciel niewielkiego obrządku koptyjskiego ${ }^{13}$. Oficjalna lista na zakończenie Soboru podaje ogółem 78 wschodnich prałatów uprawnionych do głosowania (6 patriarchów, 36 arcybiskupów, 29 biskupów i 7 opatów), z których tylko 17 odnotowano jako nieobecnych ${ }^{14}$. Ojcowie wschodni na równi $\mathrm{z}$ lacinnikami zajmowali wyznaczone im według daty święceń miejsca, wygłaszali przemówienia, zgłaszali swoje postulaty i propozycje poprawek. Dwóch spośród nich wybrano nawet do komisji soborowych, mianowicie melchickiego patriarche do komisji postulatów i armeńskiego - do znacznie ważniejszej komisji, zwanej Deputacją dla Spraw Wiary ${ }^{15}$. Stanowisko biskupów wschodnich $w$ sprawie ogloszenia nieomylności papieża jako dogmatu wiary nie było jednolite, nawet do tego stopnia, że linia podziału między ,infallibilistami" a "antyinfallibilistami" przebiegała przez sam środek poszczególnych obrządków ${ }^{16}$. Za to niemal wszyscy Ojcowie wschodni, każdy na swój sposób, występowali w obronie interesów odlączonych Kościolów Wschodu. Już sama ich obecność musiała oddziaływać ekumenicznie, wskazywała bowiem na to, że obok łacińskiego istnieją jeszcze inne obrządki w Kościele katolickim, lecz ponadto przypominała Ojcom Soboru o odłaczonych Kościołach wschodnich, posiadających duże podobieństwo do tych, które reprezentowali obecni na auli obrad. Jak dalece dyskusja soborowa dotyczyła kwestii ekumenicznych, najlepiej ilustruja przemówienia trzech unijnych patriarchów Wschodu. Dwa pierwsze wystąpienia, patriarchów chaldejskiego i melchickiego, nosily bezspornie silne znamię ducha ekumenizmu, podczas gdy trzecie przernówienie, wygloszone przez patriarchę armeńskiego, należy zaliczyć raczej do opozycji.

\section{Patriarcha chaldejski - Józef Audo}

Pierwsze przemówienie, chaldejskiego patriarchy Babilonu Józefa Audy ${ }^{17}$, zostało wygłoszone bardzo wcześnie - 25 I 1870 r.,

$12 \mathrm{M}$ a n si, 49, $189-191$.

13 Był nim Abraham B c i a i, tytularny biskup z Cariopolis i administrator apostolski $w$ Egipcie dla Koptów.

14 Zob. wykaz u M a n s i g o, 53, 1061-1094.

15 Tamże, 50, 38-39 i 161 .

16 Znamiennym tego przykładem jest mały obrządek wschodni z językiem rumuńskim; abp z Fagaras $W$. V a n c S a był przeciwnikiem tej definicji, natomiast $z$ Oradea Mare J. Pap $p-S z i l$ agy i jej zwolennilkiem. Również w chaldejskim i melchickim obrządku nie wszyscy biskupi stali po stronie swoich patriarchów; podobnie było i w obrządku armeńskim. Przyczyny takiego nastawienia wśród grona Ojców wschodnich są dzisiaj trudne do zrozumienia (Por. B e umer, art. cyt., s. 393, przyp. 18 i 19; U. B etti, La Constitutione Dommatica, ,Pastor Aeternus" del Concilio Vaticano I, "Spicilegium Pontificii Athenaei Antoniani", 14 (1961) 505).

i7 $\mathrm{M}$ a n s i, 50, 514-516. 
a więc w okresie, kiedy dyskusja wokól prymatu papieskiego jeszcze się nie rozpoczęła. Patriarsze Józefofi zależało najwidoczniej na rozbudzeniu zainteresowań Ojców soborowych trudnym położeniem unijnych Kościołów Wschodu. Jego żądanie szło przede wszystkim w kierunku niewprowadzania żadnych zmian $w$ ich kościelnej dyscyplinie. W związku z tym, powodowany ekumeniczna troska, patriarcha ten nie wahal się stwierdzić: „Zmiany, których nie możemy przyjąć, doprowadzą w końcu do tego, że nasi odłączeni bracia jeszcze bardziej oddalą się od unii, co byłoby przeciw. ne milości tego, który pragnie, aby wszyscy ludzie mieli życie" 18. Godny jest tu uwagi sposób wyrażania się: „nasi odłączeni bracia” (fratres nostri separati), który w okresie Vaticanum I nie był jeszcze używany. Zdaniem J. B e u mera jest rzeczą niepewną, czy sformułowanie fratres nostri separati można przypisać bezpośrednio chaldejskiemu patriarsze, zwłaszcza jeśli się zważy, że nie jest wiadome, komu należy zawdzięczać łacińskie tłumaczenie tego tekstu ${ }^{19}$. Końcowe słowa wystąpienia tego patriarchy brzmiały następująco: „Sprawiedliwość domaga się, a wierność [danym obietnicom] żąda, ażeby utrzymanie przywilejów stolic patriarszych nie doznało żadnego uszczerbku" 20 . W ten sposób usiłował patriarcha bronić dawnego "status quo", który niejednokrotnie po Soborze Florenckim doznawał uszczerbku ze strony Rzymu. Taki sposób postępowania wydawał mu się niezgodny $\mathrm{z}$ prawdą historyczna, a na pewno przeciwny należnej tym stolicom czci i poszanowania. Mimo tej obrony mowa patriarchy Józefa nie wzbudziła większego poruszenia ani też nie znalazła zasłużonego odźwięku w czasie obrad. Zapewne spowodowane to było niekorzystnie wybranym terminem wygloszenia tego przemówienia i związanym $z$ tym brakiem przygotowania u Ojców soborowych do problematyki ekumenicznej; a byé może i ta okoliczność, że patriarcha nie wygłosił tego przemówienia osobiście, lecz poprosił o jego odczytanie zaprzyjaźnionego: z nim francuskiego arcybiskupa 21.

\section{Patriarcha melchicki - Grzegorz Jussef $z$ Antiochii}

Znacznie żywszą reakcję ws̉ród uczestników Soboru wywołało drugie przemówienie, wygloszone na auli przez melchickiego pa--

18 Tamże, 516.

19 B e u m e r, art. cyt., s. 394, przyp. 23.

20 „Omnino ergo iustitia postulat, exigitique fidelitas ne conservationi praerogativarum sedium patriarchalium aliquod detrimentum afferatur" (M a n s i, 50, 516).

21 Akta soborowe pod datą 26 I t. $r$. notują: ,Deinde ad ambonem successive vocati sunt (...) patriarcha Babylonensis, qui observationes chaldaice scriptas, et in linguam latinam versas, de venia eminentissimorum praesidum, legendas dedit reverendissimo domino Victori Bernardeu archiepiscopo Senonensi" (M a n s i, 50, 498). 
triarchę Grzegorza Jussefa z Antiochii. Patriarcha ze swoją mową wystąpił $19 \mathrm{~V} 1870 \mathrm{r}$. ${ }^{22}$, a więc w czasie, gdy już rozpoczęła się publiczna dyskusija wokół sprawy prymatu i nieoniylności papieża ${ }^{23}$. Na wstępie swego przemówienia patriarcha zaznaczył, że bynajmniej w niczym nie chce podważać prawa papieskiego prymatu, jednak - wydawało mu się - że pewne sformułowania użyte $\mathrm{w}$ schemacie pod adresem Greków są sprzeczne $\mathrm{z}$ duchem unii, bowiem ,kanony, które zawierają się w konstytucji, nakładają wprost i bezpośrednio anatemę na Greków, których Kościół w swej dobroci nigdy dotąd publicznie nie ekskomunikowal. Jest rzeczą znaną - przypominal $\mathrm{w}$ dalszym ciągu mówca - jak daleką ostrożność zachowali Ojcowie trydenccy w sprawie wspólnych nam ze schizmatylkami przepisów odnośnie do małżeństwa. Swięty Synod tylko ze względu na Greków wzbraniał się przed pozytywnym i bezpośrednim potępieniem ich poglądów co do rozwiązalności małżeństwa w wypadku cudzołóstwa; zastosowano raczej pewne sformułowanie i oświadczono jedynie, że nauka Kościoła o małżeństwie nie zawiera żadnego błędu" ${ }^{24}$. Mówca zaatakował także w schemacie stwierdzenie, że Grecy są naznaczeni nie tylko piętnem schizmatyków, ale również heretyków ${ }^{25}$. Występując w swoim przemówieniu przeciw anatematyzmom, patriarcha Jussef uczynił aluzje do uchwały Soboru Florenckiego, zachowania której domagal się z całą stanowczością, gdy stwierdzał: „powszechnie znany jest kanon florencki o prymacie Biskupa Rzymu opierającym się na prawie Bożym, o jego przywilejach i pełnomocnictwach oraz o tym, jak należy go rozumieć (...) Poza tym odnawiamy reguły - tak brzmiała uchwała Soboru - przekazane w kanonach dla pozostałych czcigodnych patriarchów (...) $\mathrm{w}$ ten sposób, aby w niczym nie naruszać ich praw i przywilejów" 26. Klauzula unijnego Soboru Florenckiego,

22 Tamże, 52, 133-137.

23 Dnia $14 \mathrm{~V}$ t. $r$. rozpoczęla się publiczna dyskusja nad schematem konstytucji Pastor aeternus, która trwała przez 2 miesiące aź do jej uchwalenia 18 VII $1870 \mathrm{r}$. Dyskusję tę szczegółowo omawia B o ga cki, dz. cyt., s. $332-356$.

${ }_{24} \mathrm{M}$ a $\mathrm{n} \mathrm{s} \mathrm{i,} \mathrm{52,} 134$.

25 „Praeterae Graeci appellantu.1 schismatici, id est seiuncti ac divisi (...). At per has definitiones anathemate roboratas hoc fundamentum i[concilii Florentini] eversum est, et illis in numero haereticorum relegandi erunt; et consequenter maius gravamen maiorque difficultas ad eorum cum ecclesia Romana reconciliatonem interponitur" (Tamże).

20, ,...) Renovantes insuper ordinem traditum in canonibus caeterorum venerabilium patriarcharum (...) salvis videlicet privilegiis omnibus et iuribus eorum" (Tamże). Uchwała florencka została zacytowana przez Jussefa w sposób niepełny, lecz bez istotnego uszczerbku dla jej sensu. Tekst w jego pełnym ujęciu znajduje się u Mansiego, $31 \mathrm{~B}$, 1697-1698; Szczegółowe omówienie postanowień Soboru Florenckiego na temat przywilejów patriarszych podaje Th. A. Ka n e, The Jurisdiction of the Patriarchs of the Major Sees in Antiquity and in the Middle Ages, Washington 1949, s. 89-90. 
zdaniem Jussefa, oznaczała w pewnej mierze jakby ograniczenie prymatu, a jednocześnie stanowiła nadzieję umożliwiającą doprowadzenie Greków, tak uporczywie trzymających się swych dawnych tradycji, do posłuszeństwa względem Stolicy Apostolskiej 27. W końcowych fragmentach swego wystąpienia patriarcha sięgnąl do niemal zaklinających słów: „Jeśli komukolwiek leży na sercu, ażeby wierni greckiego obrządku utrzymali się i żeby w ogóle jedność Kościoła mogła istnieć w łączności z papieżem, jeżeli na koniec te drzwi, przez które cały wschodni Kościół możliwie prędko mógłby wrócić do jedności z Kościołem, nie mają się na zawsze zamknąć, to $z$ najusilniejszym naleganiem proszę, ażeby przeszkody tego rodzaju nowej definicji zostały usunięte (ut haec obstacula novarum eiusmodi definitionem removeantur)" 28. Zachęcając do łagodnych określeń, Jussef dostrzegał, że zajęta postawa wobec Greków jest niezgodna $z$ prawdą historyczną, a na pewno przeciwna należnej miłości. „Ponieważ rozważamy temat wiary - konkludował melchicki patriarcha - należy unikać pozostawiania na uboczu miłości; tutaj bezwzględnie musi znaleźć się miejsce na miłość, ażeby Grecy, będący na zewnątrz, zostali pociągnięci i wstąpili do owczarni Pana pod jedynym widzialnym Pasterzem" 23.

Trzeba stwierdzić, że z taką żarliwością nie wystąpił na tym Soborze $\mathrm{w}$ interesie odłączonych żaden biskup, podczas gdy Jussef szedł tylko dalej po drodze, którą sam weześniej rozpoczął. I tak np. już 12 III 1866 r. dołączył on do swej, pozytywnej zresztą, odpowiedzi na rzymskie zaproszenie do udział̌u $w$ Soborze, skargę na nadużycia ze strony lacińskich misjonarzy ${ }^{30}$, a 18 I $1870 \mathrm{r}$, prawdopodobnie z jego inicjatywy, został złożony na piśmie wniosek przeciw zapowiedzianemu ogłoszeniu definicji nieomylności papieskiej, który razem $\mathrm{z}$ nim podpisalo jeszcze kilku innych biskupów obrządku melchickiego i chaldejskiego ${ }^{31}$. To ekumeniczne zaangażowanie Jussefa dawało wyraz prawdzie, że dla jedności chrześcijan więcej znaczyły miłość, zjednoczenie z Bogiem, gorące pragnienia niż wszystkie polemiki, dyskusje, argumentacje i dogmatyczne określenia. Tej orientacji ekumenicznej — śmiałej i odważnej jak na owe czasy - nie można niczego także zarzucić i ze stanowiska współczesnej teologii. Nie ulega wattpliwości, że Jussef wypowiedział się

27 „Haec clausula est et fuit semper sicut fundamentum, quo summi potifices innixi de revocandis schismaticis ad unitatem petractarunt (...). Haec, inquam, clausula est unica tabula et spes, quae remanet, ut graeci, conservatores tenacissimi suarum antiquitatem, ad obedientiam sedi apostolicae praestandam reduci possunt" (M a n s i, 52, 134); B e u$\mathrm{mer}$, art. cyt., s. 396. Godne jest tu podkreslenia psychologiczne zrozumienie przez Jussefa mentalności ludzi Wschodu.

28 Tamże, 136.

${ }^{29}$ Tamże, 137.

30 Tamże, 51, 683.

a1 Tamże, 49, 200; B e u mer, art. cyt., s. 396, przyp. 34 . 
za nieprzerwanym trwaniem prymatu, płynącego z ustanowienia Bożego, ale obok tego domagał się zachowania kościelnego prawa przywilejów patriarszych ${ }^{32}$. Można było jedynie - co słusznie zauważa cytowany Beumer - znacznie wyraźniej zaakcentować, że autonomia i przywileje wschodnich patriarchów mają być rozumiane tylko relatywnie, stąd interwencja papieża w wewnętrzne sprawy każdego patriarchatu w określonych warunkach jest zawsze prawnie uzasadniona ${ }^{33}$. Tak czy inaczej należy stwierdzić, iż żadania patriarchy Jussefa, o których jeszcze później przypomni Ojcom Soboru, mianowicie że elsskomunika na przeciwników prymatu nie powinna mieć miejsca oraz że przywileje patriarchów wschodnich musza być przy tym bezwarunkowo utrzymane, zostały wysunięte $\mathrm{w}$ duchu naprawdę ekumenicznym.

\section{Patriarcha armeński - Antoni Piotr IX Hassun}

Trzecie wystąpienie na auli obrad, które należy tu omówić, to przemówienie armeńskiego patriarchy z Cylicji Antoniego Piotra IX Has una, wygłoszone $23 \mathrm{~V} 1870 \mathrm{r.}{ }^{34}$. Głównym zamierzeniem

32 Różnica między Boskim prawem prymatu, a kościelnym prawem odnośnie do uprzywilejowanego stanowiska 5 patriarchów jest nader jasno wyrażona przez Jussefa w następującym zdaniu: „Apud Orientales a tota antiquitate usque ad haec tempora hic est et viget ecclesiae typus, quod scilicet universa Christi ecclesia in quinque patriarchiis iure canonico distribuatur, et in uno aliorum principe iure divino colligatur" (Tamże, 52, 135).

${ }^{33}$ B e um er, art. cyt., s. 396 n.; Rozpatrywana pod tym kątem autonomia patriarchów wschodnich (zwana często kanoniczną lub relatywną) rozciąga się na dziedzinę kanoniczną, dyscyplinarną oraz liturgiczna. W. de Vries, profesor Instytutu W/schodniego $\mathrm{w}$ Rzymie, tak opisuje autonomię patriarchalnego Wschodu: 1- Wschód swobodnie wybieral swych patriarchów i biskupów, sam dysponował swymi diecezjami erygując nowe lub podnosząc ich stopień w hierarchii; 2- Wschód samodzienie regulowal swoja liturgię i ustawodawstwo kanoniczne; 3Wschód wreszcie sam dysponowal duchowieństwem i wiernymi w sprawach dyscypliny ( $L a S$. Sede ed $i$ patriarcati cattolici d'Oriente, „Orientalia Christiana Periodica", $27(1961)$, fasc. 2, s. 318). Autonomia patriarchów była niemal całkowita we wszystkich tych dziedzinach. Oczywiście, nie oznaczała ona niezależności ani też odgrodzenia się od innych Kościołów katolickiej oikoumene, ani tym bardziej izolacji, ponieważ należało uwzględniać „consensus fidei" $\mathrm{z}$ innymi „Kościołami głównymi"; trzeba było czuwać nad zachowaniem związków ,communio". To właśnie poczucie przynależności do Kościoła powszechnego, wola pozostania $w$ nim były czynnikiem zachowania rówaowagi pomiędzy „autonomią" a "communio", powszechnością a Kościołem lokalnym w pierwszym tysiącleciu (Por. L. Lah a m, Le patriarcat d'Antioche au premier millénaire, „Orientalia Christiana Analecta", 181/1968/115136).

${ }^{34}$ M a n s i, 52, 192-202; Cytowany B e u mer podaje 11 chyba omyłkowo - inną datę tego wystąpienia, mianowicie 23 IIr t.r. (art. cyt., s. 397). 
patriarchy, co jasno wynika już z samego początku jego mowy ${ }^{35}$, było podważyć pojęcie prymatu ukazane przez Jussefa. Hassun, opierając się na tekstach skrypturystycznych i patrystycznych oraz na kanonach Soborów, ukazał obraz papieskiego prymatu mocno odbiegający od tego, jaki nakreślił patriarcha Kościola melchickiego. Natomiast co do zacytowanych przez siebie fragmentów z Soboru Florenckiego twierdził, jak następuje: „W naszej konstytucji (Vaticanum I) ze względu na jej dogmatyczny charakter znajduje się tylko jeden dogmatyczny dekret (...) Ów Synod (Florencki) mógk zamieścić dyscyplinarne reguły dotyczące stolic patriarszych, ponieważ nie ułożył on żadnych własnych kanonów dyscyplinarnych; my jednak, którzy osobno (separatim) traktujemy dyscyplinę kościelną, nie możemy pomieszać obydwu, aby nie powstało wrażenie, jakoby to, co jest $z$ ustanowienia ludzkiego, zostało przeniesione na Boskie ùrządzenia" 36. Patriarcha armeński nie mógł oczywiście przewidzieć żadnych uchwał dyscyplinarnych, powinien był jednak pomyśleć 'o psychologicznym rozgoryczeniu wiernych Wschodu na skutek przemilczenia przywilejów patriarszych. Kanon florencki nie oznaczał dla niego żadnego ograniczenia papieskiej władzy prymatu. W kwestii jego rozumienia Hassun wypowiedział się zupełnie jednoznacznie: „Żadną miarą rzymscy papieże nie mogli i nie mogą potwierdzić rzeczonej autonomii Kościołów wschodnich i przez to pozbawić siebie najwyższej władzy przysługującej prymatowi w jego istocie, mianowicie kierowania tymi Kościołami" 37. Na zakończenie Hassun podał streszczające oświadczenie: „Wiemy z doświadczenia, że ci wszyscy spośród ludzi Wschodu dopóty pozostawali w jedności katolickiej, dopóki zachowywali w swoim myśleniu mocne i wyraźne pojęcie papieskiego prymatu, z chwila zaś jego zacierania poczynali się chwiać" 38. Jakkolwiek trzeba przyznać, że Piotr IX Hassun przemawiał całkowicie w duchu późniejszej definicji i że jego krytyka przemówienia Jussefa w niektórych szczegółach wydaje się słuszna, należy jednak żałować, że ekumeniczny

35 Tamże, 192: „Quae tribus abhinc diebus reverendissimus patriarcha Antiochenus Graeco-Melchitarum in hac aula conciliari disseruit (...) tam gravia sunt, tamque aliena videntur a genuina notione primatus Romani pontificis, ut ea tacitus praeterire nequam (...)".

${ }^{36}$ Tamże, 200.

37 Tamże: „Nullo pacto potuisse aut posse Romanos pontifices (...) assertam autonomiam ecclesiarum orientalium confirmare, seque privare suprema potestate ipsi primatui essentialiter inhaerente easdem ecclesias sicut caeteras pascendi et gubernandi". Zupelnie otwartą sprawą jest, czy papieże w wykonywaniu swego najwyższego urzędu pasterslkiego względem Kościołów patriarchalnych nie mogliby ingerować $\mathrm{w}$ sposób umiarkowany _- $\mathrm{w}$ ich wewnętrzne sprawy. Tego rodzaju ingerencja nie byłaby jednak uzasadniona prawem Bożym, a tylko kościelnym. Pozytywna odpowiedź na tę kwestię oddałaby w całości sens wypowiedzi Jussefa (por. Beumer, art. cyt., s. 398, przyp. 39).

${ }^{38} \mathrm{M}$ a $\mathrm{n} \mathrm{s} \mathrm{i}, 52,202$. 
wzgląd na położenie braci odłączonych prawie nie jest widoczny $\mathrm{w}$ jego wystąpieniu; równocześnie stosowne jest w tym miejscu pytanie, czy jego glos można oceniac jako obiektywny i wolny od uprzedzeń w kwestii wschodniokościelnych przekonań, jeśli weźmie się pod uwagę choćby to, że obrządek armeński obok maronickiego dość wcześnie i w największym ze wszystkich pozostałych obrządków wschodnich zakresie przyjął bądź też musial przyjąć pewne korektury na korzyść obrządku lacińskiego. Nadto warto pamiętać jeszcze i o tym, że Hassun $z$ powodu wewnetrznych trudności w swoim patriarchacie był zdany na poparcie Rzymu; z czasem, już po Soborze, poczuł się nawet zmuszony do zrezygnowania z urzędu patriarchy, za co papiez zamianował go kardynałem ${ }^{39}$.

\section{Dalsze ekumeniczne wystąpienia Ojeów soborowych}

Przemówienia 3 wschodnich patriarchów wywolały, chociaż w nierównym stopniu, dość żywą reakcję $\mathrm{w}$ auli soborowej, i to zarówno wśród biskupów wschodniego, jak i lacińskiego obrządku. Reakcja ta była przeważnie pozytywna. Wprawdzie przemówienia wschodnich przedstawicieli rzadko były wygałszane na kongregacjach generalnych, niemniej jednak $\mathrm{z}$ ważniejszych należy tu odnotować nastẹpujące: $28 \mathrm{~V} 1870 \mathrm{r}$. przemawial rumuński biskup z Oradea Mare (Siedmiogród) J. P a p p-Szil ág y i 40; 2 VI t. r. inny rumuński arcybiskup $z$ Fagaras Jan $\mathrm{Vancs}$ a ${ }^{41}$; $\mathrm{w}$ tydzień później, 9 VI, syryjski arcybiskup z Mossulu (późniejszy patriarcha Antiochii) Cyryl Behnam Benni $42 ; 11$ VI ponownie $\mathrm{Papp}$ - S zilág y i ${ }^{43} ; 14$ VI również po raz drugi melchicki patriarcha J ussef ${ }^{44} \mathrm{i}$ w tym samym dniu abp $\mathrm{V}$ ancs a ${ }^{45}$. Wszyscy wyżej wymienienin, $\mathrm{z}$ wyjątkiem syryjskjego abpa Benniego, podjęli sprawy ekumeniczne.

Powołanie się na sławną, niemalże epokową mowę melchickiego patriarchy Jussefa jest najwyraźniejsze u bpa Papp-Szilágyi'ego, który prawie dosłownie przytacza jego wypowiedź: „Jeśli cały schemat nie zostanie poprawiony $\mathrm{w}$ wymieniony sposób, na zawsze zamkną się drzwi, przez które Grecy mogliby kiedyś wrócić do unii z rzymskim Kościołem" ${ }^{\prime 6}$.

39 Por. na ten temat: G. A m a d u n i, „Hassun”, (W:) Enciclopedia Cattolica, (Città del Vaticano 1951), t. VI, kol. 1374.

${ }_{40} \mathrm{M}$ a n s i, 52, 309-312.

41 Tamże, 380-386.

42 Tamże, 551-561.

43 Tamże, 601-605.

${ }^{44}$ Tamże, 671-676.

45 Tamże, 690-697.

46 "Nisi praedicto modo totum schema reformetur, porta perpetuo claudetur, ne umquam Graeci ad unionem cum Romana ecclesia redire possint" (Tamże, 1097). Wypowiedź rumuńskiego przedstawiciela episko- 
Melchicki patriarcha Jussef wystąpił po raz drugi ze swoimi żądaniami, które dotyczyły usunięcia anatemy na przeciwników definicji nieomylności papieża, oraz dopominal się uwzględnienia w dekrecie soborowym przywilejów patriarszych (salvis privilegiis omnibus et iuribus eorum) ${ }^{47}$. Inni biskupi wschodni podtrzymywali przede wszystkim pierwszy postulat. W tym duchu przemawiali np. dwaj chaldejscy biskupi $\mathrm{H}$ in d i 49 i $\mathrm{F}$ a r s o 49 . We wszystkich jednak tych wystąpieniach trudno doszukać się jakichś istotnych postępów w odniesieniu do tego, co poruszył juz w swojej mowie patriarcha Jussef. Z wystąpienia rumuńskiego abpa Vancsy warto przytoczyć jedynie zdanie, w którym zwraca uwagę obradujących na Soborze na trudna sytuację jego wlasnego Kościoła ${ }^{50}$; poza tym z jego słów można wyczytać glęboką znajomość religijnych i duchowych odrębności Wschodu 51.

Grupa Ojców przychylnie usposobiona do możliwości ogłoszenia dogmatu o nieomylności papieża wykazywała się większą liczbą zwolenników niż grupa jej przeciwna. Biskupi łacińscy, którzy zaliczali się do mniejszości przeciwników tej definicji, wykorzystali wypowiedź Jussefa dla własnych $w$ tej kwaestii poglądów. Nie wszyscy oni jednakże powoływali się na mowę melchickiego patriarchy tak bezpośrednio i otwarcie, jak to uczynił np. weggierski prymas abp Jan Simor z Gran. Tenże mówca w swoim wystąpieniu z $20 \mathrm{~V} 1870 \mathrm{r}$. wyraźnie powołal się na przemówienie Jussefa, wygłoszone poprzedniego dnia, i podobnie jak on zalecał ostrożność, jaka cechowała trydenckich Ojców soborowych, dotycząca głównie kwestii małżeństwa jako przykład do naśladowania w obecnym Soborze Watykańskim przy uchwalaniu definicji nieomylności i prymatu 52. Również jego rodak, biskup z Csanád i Temesvar Aleksander B onn a z, miał na myśli zapewne wypowiedź Jussefa, gdy $28 \mathrm{~V} 1870 \mathrm{r}$. rozprawiał na temat olbrzymich trudności stojących przed zjednoczeniem odłączonych Greków, chociaż powołał się on tylko na soborowe przemówienie ,pewnego wschodniego przedstawiciela", nie wymieniając przy tym żadnego nazwiska ${ }^{53}$. Jego

patu posiada wartość przede wszystkim dalatego, iż Papp-Szilágy i opowiedzial sie zdecydowanie za ogloszeniem delinicji papieskiej nie-omylności.

17 Zdaniem mówcy powinny być z Soboru Florenckiego dolączone do schematu następujące słowa: "Renovantes insuper (...) salvis privilegiis omnibus et iuribus eorum" (Tamże, 1086, n. 13).

48 Tamże, 1272 , n. 29,31 n.

49 Tamże, 1273, n. 36 B.

50 Tamże, 384; B e u m e r, art. cyt., s. 399.

51 M a n i, 52, 381, $384 \mathrm{n}$.

52 Tamże, 141; B eum er, art. cyt., s. 400.

53 „Auđistis, reverendissimi patres, nuper orientalem pro orientalibus verba facientem; sinite quaeso ut hodie occidentalis in favorem sacrae unionis pauca verba faciat, vel ex eo etiam ut orientales in hoc 
ekumeniczne poglądy są wyrażone bardzo wymownie $\mathrm{w}$ zdaniu o następującej treści: „Należy się obawiać, że na skutek tej nowej nauki, jeśliby teraz zostala zdefiniowana, powstanie nowy mur, wyższy niż dotąd, między Wschodem a Zachodem" 54. Nie trudno więc ustalić, że słowa przedstawiciela węgierskiego episkopatu mają to samo znaczenie, co słowa wypowiedziane przez Jussefa.

Sporo też uwag - w oparciu o postanowienia soboru we Florencji - napłynęło ze strony łacinskich biskupów w kwestii zachowania przywilejów wschodnich patriarchów. Zgłaszane $\mathrm{w}$ tej materii postulaty przybierały jednak dość rozwlekłą formę. Między innymi bp Jean B r a vard z Coutanaces proponowal, aby pierwszy paragraf schematu konstytucji wzbogacić, w duchu Soboru Florenckiego i Lateraneńskiego, o następujący dodatek: „bez naruszania praw nabytych przez niektóre diecezje $z$ racji nadania, zwyczaju, konkordatów lub innych ważnych tytułów" 55 . Jeszcze bardziej niesprecyzowane są sformułowania dotyczące chrześcijan wschodnich u tych Ojców, którzy wypowiadali się na temat niebezpieczeństw zagrażających jedności Kościoła 56 . Jak długo takie lub im podobne wypowiedzi rozważa się każdą $\mathrm{z}$ osobna, trudno $\mathrm{w}$ nich dostrzegać przejawy istniejących u Ojców soborowych tendencji o zabarwieniu ekumenicznym; z chwilą jednak, gdy złączy się je $z$ wypowiedziami śmielszymi, staje się widoczne, że wystą-pienia wschodnich patriarchów, zwłaszcza Jussefa, pozostawiły ślad $\mathrm{w}$ pamięci zgromadzonych $\mathrm{w}$ auli, a przynajmniej u znacznej ich części.

\section{Sprzeciwy wobec ekumenicznych żądań Wchodu}

Oczywiście nie można było oczekiwać, że śmiałe wystąpienia. unijnych biskupów, przede wszystkim melchickiego patriarchy Jus-

benevolentiae et propensi animi documentum reperiant" (M a nsi, 52, $302)$.

54 ,Timendum est ne per novas has doctrinas si definitae fuerint, novus isque altior murus erigatur inter orientem et occidentem" (Tamże, 303).

55 „Huic primo paragrapho addantur haec verba ad sensum Florentini et Laternanensis: salvis iuribus, quae concessione, consuetudine, concordatibus, aut alio aequo titulo quibusdam dioecesibus inhaerent" (Tamże, '1081-1082, n. 5). Por. B e u m e r, art. cyt., s. 400 n.

${ }_{50} \mathrm{~W}$ podobny sposób wystąił np. bp z Lacedonii Francesco M ajor sin $\dot{1}$, który złożył 2 postulaty: 1. "Nihil aliud addendum, ne controversiae suscitentur de novo cum orientalibus, uti auditum est ex: ambone" (M a n s i, 52, 1272, n. 30); i z. „Omnino non placet ut definiatur uti dogma fidei (...) ob gravissima pericula defectionum et schismatis (...) velut a pluribus concilii patribus ex ambone auditum est" (Tamże, 1276, n. 50). Szczególnie obszernego przedstawienia Soboru Florenckiego i jego stosunki do Greków usiłowal dokonać - prawdopodobnic zachęcony do tego wystąpienia Jussefa - abp z Reims Jean Land ri ot 9 VI 1870 r. (por. tamże, 561-567). 
sefa, spotkają się na Soborze z jednomyślnym uznaniem i aprobatą. Ponieważ przedstawiony projekt definicji nieomylności papieskiej został do pewnego stopnia zagrożony, a przynajmniej osłabiony, obrońcy papieża musieli konsekwentnie wystąpić przeciw ekumenicznym żądaniom Wschodu w ogóle.

Pomijając $w$ tym miejscu przemówienie armeńskiego patriarchy Hassuna, którego główna treść została przytoczona już wyżej, trzeba, jeśli chodzi o wschodnich przedstawicieli, przytoczyć na pierwszym miejscu wywody syryjskiego abpa Behnama Benniego z 9 VI 1870 r. Nawiązanie do przemówienia Jussefa jest tu bardzo wyraźne, gdyż Behnam zupełnie otwarcie zaatakowal swego dawnego kolegę z okresu studiów w Rzymskim Kolegium Propagandy ${ }^{57}$. Wystąpienie $w$ obronie praw papieża również i $w$ diecezjach wschodniego obrządku jest wprawdzie samo przez się chwalebne i pożądane, ale całkiem niezrozumiałe jest u Benniego zapoznanie spraw ekumenicznych w tym jednym choćby zdaniu, w którym stwierdza, że nie ma niczego bardziej odpowiedniego dla nawrócenia schizmatyków ,nad uchwalenie na obecnym Soborze dekretów dotyczących papieża" 58.

Podobne petycje naplywały i od innych Ojców Wschodu. Bynajmniej nie inaczej brzmiała propozycja poprawki, której autorem był armeński bp z Erzerum S. Melch is e de $\mathrm{chi}$ a n. Domagał się $\mathrm{w}$ niej stanowczo, aby papieską władzę prymatu uwydatnic jeszcze bardziej, niż to zostało uczynione $w$ schemacie, $i$ to nie tylko generalnie dla całego Kościoła powszechnego, ale także wprost dla wszystkich Kościolów lokalnych ${ }^{59}$. Nie ulega przeto wątpliwości, że na tego rodzaju wypowiedziach zaciążył w pewnej mierze autorytatywny wpływ patriarchy Hassuna.

Najbardziej charakterystyczny przykład zdecydowanego oporu większości soborowej łacińskich biskupów wobec ekumenicznej postawy Wschodu stanowi obszerne przemówienie z $20 \mathrm{~V} 1870 \mathrm{r}$., wygloszone przez Spiridiona $\mathrm{M}$ a d d a le $\mathrm{n}$ ę, urodzonego i wykształconego w Grecji, którym był łaciński abp wyspy Korfu 60 . Chociaż nie wymienia się $w$ nim żadnego nazwiska, to jednak niewatpliwie jest ono wymierzone przeciw patriarsze Jussefowi. Maddalena wprost upodobal sobie w opisywaniu i napiętnowaniu niedociągnięć Kościoła prawosławnego aż do najdrobniejszych szczegółówi. $\mathrm{W}$ jakże ostrym tonie streszcza on wynik swego przemówienia choćby tylko w tym jednym zdaniu: „Grecy są, że tak powiem, zatwardziali $w$ swojej schizmie $i \mathrm{z}$ powodu swej dumy $z$ trudem

57 Tamże, 552.

58 ,Mea sententia arbitror, nihil opportủius esse ad eorum (schismaticorum) conversionem ut decreta de Romano pontifice in hoc concilio sanciantur" (tamże, 560).

59 Tamże, 1272 , n. 32.

60 Tamże, $151-155$. 
uczynią choćby jeden krok na drodze ku osiągnięciu jedności" 61. Pozostawmy na uboczu sprawę, czy Maddalena wydając taki osąd postępował jednostronnie i przesadnie. Gdyby jednak mówca ten był przejęty duchem ekumenizmu, na pewno wyszukałby inne możliwości zaradzenia tym niedociągnięciom, które zarazem przecierałyby droge ku zjednoczeniu, a przynajmniej nie utrudniałyby jej jeszcze bardziej. Za pozytywny ewentualnie wkład można uważać najwyżej to, że Maddalena, uznając sprawę jedności wiary za najpilniejszą, a której brak dostrzegal $u$ ortodoksyjnych chrześcijan, widział jej osiągnięcie $\mathrm{w}$ tym, że wszyscy zgodnie przyjmą prawdę - o prymacie ì nieomylności papieża ${ }^{2}$. Tę samą myśl wyraził $24 \mathrm{~V}$ 1870 r. bp Józef H. S a l a s podkreślajace, ze gorliwość o zbawienie dusz nie może prowadzić do jakiejkolwiek rezygnacji z otwartego i pełnego wyznawania prawd wiary katolickiej, bowiem takim postępowaniem, taką obawą przed niebezpieczeństwem, nie podobna - według niego - nawrócić do świętego Kościoła ani jednego schizmatyka czy akatolika ${ }^{63}$. Tak jak pierwsza część tej wy.* powiedzi jest słuszna, tak druga budzić może pewne zastrzeżenia; nie wolno bowiem zapominać, że przedłożenie prawdy winno zaw:sze iść w parze raczej z roztropnością i należną miłościa.

Wprost decydującym dla ogólnej postawy Soboru względem odłączonych obrządków Wschodu było wystąpienie 5 VII 1870 r. bpa $z$ Treviso Fryderyka Zinelli e go. Zinelli - jako relator Deputacji dla Spraw Wiary - oficja!nie stwierdzil, że w dogmatycznej konstytucji nie może być mowy o przywilejach dla stolic patriarszych, gdyż zaliczają się one do rzędu kwestii dyscyplinarnych 64. Odnośnie do zniesienia ekskomuniki na przeciwników nieomylności papieskiej Zinelli w tym samym przemówieniu wyjaśnil, że w wypadku, gdyby Grecy rzeczywiście tylko odłączyli się od wspólnoty z Kościołem, byliby wówczas jedynie schizmatykami, ponieważ jednak odrzucają także prymat jurysdykcyjny papieża, opierający się, na prawie Bożym, sa heretykami ${ }^{6}$. Nie ulega tu wątpliwości, że oba wyjaśnienia relatora Deputacji były zwrócone przeciw propozycjom poprawek zgłoszonym przez Jussefa. Po tak

61 "Graeci petrifacti, ut sic loquar, in suo schismate, vi suae superbiae admodum difficiliter ad unitatem gradum facient' (tamże, 153).

62 Tamże, 155.

63 "Zelus pro animarum salute alienus esse non debet a publica et integra veritatum fidei catholicae confessione (...) Mea humili sententia tali agendi modo, tali formidine periculi ne unum quidem schismaticum aut acatholicum ad sanctam ecclesiam convertemus" (tamże, 232).

${ }^{64}$,At haec declaratio, ut saepe dictum est, non habet hoc locum, quia haec est constitutio tantum dogmatica, non disciplinaris" (tamże, 1108); B e u m e r, art. cyt., s. 404 n.

65 ,Si Graeci tantum se separaverint de facto a communione cum ecclesia, essent tantum schismatici. At qui negant primatum iurisdictioriis juris divini sunt haeretici" (tamże, 1115). 
stanowczym oświadczeniu nieco bardziej pojednawczo brzmiała reakcja Zinellego na prośby, aby nie zamykać na stałe Grekom drzwi do unii z Kościołem. Cały jego wysiłek i tutaj zmierzał do wykazania, że obowiazkiem katolickiego Kościola jest odważne: głoszenie prawd św. wiary. „Przyjdzie jednak kiedyś godzina miłosierdzia - wnikał dalej w problem Zinelli - że Bóg poruszy serca [schizmatyków], tymczasem zaś chcemy się za nich modlić i nieustraszenie definiować prawdę" 66. Niewątpliwie na wyjaśnieniach. Zinellego znać wpływ licznych interwencji biskupów należących do grupy tych, którzy wobec ekumenicznych spraw Wschodu nie okazali zbyt dużego zrozumienia. Ponieważ rozwiązanie podane przez Zinellego wyrażało - trzeba tak przypuszczać - także stanowisko Deputacji dla Spraw Wiary oraz większości łacińskich uczestników Soboru, nadzieja na uwzględnienie w tekście konstytucji ekumenicznych postulatów wschodnich przedstawicieli ostatecznie zniknęła.

\section{Zakończenie Soboru}

Dnia 18 VII 1870 r. nastąpiło uroczyste ogłoszenie konstytucji Pastor aeternus o prymacie i nieomylności papieża. Niewątpliwie pierwotny projekt uchwały przedstawiał nieomyiność papieska. w zbyt ogólnikowych terminach. Dopiero dyskusje wywołane opozycją mniejszości pozwolily na dokładniejsze określenie tej nieomylności i ograniczenie jej do uroczystego nauczania papieża całego Kościoła w kwestiach wiary i moralności w sposób ostateczny (ex cathedra). Niestety, nie wspomniano w niej ani słowem o przywilejach wschodnich patriarchów, zresztą już wcześniejsze wystąpienie relatora Deputacji Zinellego nie pozwalało żywié nadziei na ich wyrażenie w uchwale soborowej. 'Tak więc ekumeniczna postawa. patriarchy Jussefa i innych Ojców Soboru o podobnym nastawieniu nie została uwzględniona. Można wątpić, czy doszłoby do ogłoszenia uchwal dyscyplinarnych na temat przywilejów patriarszych nawet wtedy, gdyby wydarzenia polityczne nie przerwaly dalszych obrad Soboru. Należy wyrazić ubolewanie, że do takich określeń nie doszło, tym bardziej że wyjście Soboru naprzeciw odłączonym wiernym Wschodu $\mathrm{w}$ duchu ekumenicznym - pod warunkiem tylko, że teologiczne i prawnokościelne kwestie zostałyby wszechstronniej wyjaśnione - nie pomniejszylyby w niczym wagi definicji prymatu ani przywilejów papieża. W rzeczywistości nieliczni wschodni biskupi z orszaku obydwu patriarchów Audy i Jussefa,

66 „At contra, ecclesia catholica principia revelata (...) debet fortiter proclamare (...) Cum tempus misericordiae advenerit, Deus movebit corda eorum: interim precemur pro ipsis, et veritatem impavide definiamus" (tamże, 1108). Por. B e u me r, art. cyt., s. 404. 
którzy odsunęli się od końcowych postanowień Soboru, z czasemwespół z pozostałymi zwolennikami soborowej opozycji - wyrazili pełną aprobatę dla uchwalonej konstytucji 67 . Z okresu posoborowego warto zwrócić uwagę na pewien szczegói — być może sam w sobie mało ważny - niemniej jednak charakterystyczny dla kwestii ekumenizmu. 18 II $1871 \mathrm{r}$. kilkakrotnie wspominany patriarcha Jussef przesłal na ręce kardynała-prefekta Kongregacji Propogandy Wiary pismo zawiadamiające Rzym o swoim poddaniu się uchwałom Soboru, ale nie omieszkał zamieścić w nim klauzuli następującej treści: „Co dotyczy kwestii dyscyplinarnej, to za pozwoleniem Waszej Eminencji, ze względu na obecny i przyszłły rozwój katolickiej religii na Wschodzie, a zwłaszcza wśród wiernych greckiego obrządku, czuję się zobowiązany w sumieniu do oświadczenia, że trzymam się nadal tego samego zastrzeżenia, jakie uroczyście oglosił swoją formułą Sobór Florencki: bez naruszenia wszystkich ich praw i przywilejów" 68. Oświadczenie tej samej treści złożył również patriarcha Audo w swoim piśmie z 29 VII 1872 r., skierowanym bezpośrednio do pap. Piusa IX ${ }^{69}$.

I Sobór Watykański nie wydał żadnego dekretu o wschodnich obrządkach $\dot{i}$ ich patriarchach, mimo tego ze jeszcze $w$ trakcie przygotowywania regulaminu i przedmiotu obrad soborowych, została już powołana przez Kongregację Kierująca 21 IX 1867 r. specjalna Komisja dla Spraw Kościołów Wschodnich i Misji 70. Lista jej członków - zresztą dość szczupła - składała się wyłącznie z prałatów i teologów obrządku łacińskiego. Nadto cała jej działalność skupiała się wokół problemów misyjnych. 19 I $1870 \mathrm{r}$. troska o unijne obrządki wschodnie została $z$ kolei przekazana osobnej Deputacji, w skład której na ogólną liczbę 24 członków weszlo 7 przedstawicieli obrządków wschodnich ${ }^{1}$. Prace Deputacji dla Spraw Obrządku Wschodniego posuwały się niezbyt szybko, jeśli

67 M a n s i, 53, 913-1062.

68 Tamże, 942.

69 "Ciò fò colla riserva di ritenere tutti i diritti, distinzioni, privilegi, grazie, usi et tradizioni, di cui han goduto gli antichi patriarchi d'Oriente, si generali come particolari senza alcum cambiamento o alcuna differenza. E questo faccio per unirmi anch'io a tutti i padri della s. chiesa cattolica, patriarchi cioè e vescovi orientali ed occidentali" (tamże, 943). O późniejszych losach patriarchy Audy i jego krontrowersjach z Rzymem por. Ch. Ko rolevskiej, „Audo", (W:) Dictionnaire d'Histoire et de Géographie Ecclesiastique, Paris 1931, t. V, kol. 317-356.

${ }_{70} \mathrm{M}$ a n s i, 49, $985 \mathrm{n}$. Obok niej utworzono jeszcze 5 innych komisji: teologiczno-dogmatyczną, dla spraw karnosci koscielnej, dla spraw zakonników, dla spraw polityczno-kościelnych i ceremonialną. Por. R. A ub e r t, Vatican I, Paris 1964, s. 54-56.

${ }_{70}$ Wzorem V Saboru Lateraneńskiego liczbę członków każdej Komisji ustalono na 24. Poszczególne Komisje bullą Multiplices inter zostaly określone mianem "Deputacji” (M a n si, 49, 610 C). Por. B o g a c ki, dz. cyt., s. 213 , przyp. 143 . 
dopiero 28 VII 1870 r., a więc już po zakończeniu głównych prac Soboru, doręczyła ona obecnym w Rzymie Ojcom niewielki schemat pt. "Schema constitutionis super missionibus apostolicis" 72. Bioracy udział w pracach tej Deputacji biskupi Wschodu mieli jednak słuszny powód do złożenia zażalenia z uwagi na niezrównanie pod względem godności ich własnych obrządków z łacińskim 73. Jeszcze w tym samym miesiącu - lipcu - Deputacja wydała drugi schemat o obrządkach (Schema de ritibus), nieco lepief odpowiadający potrzebom czasu, a przede wszystkim dążący do zasadniczej równości wszystkich obrządlsów 74. W aktach Soboru nie: zostało jednak zaznaczone, czy na temat jego treści odbyla się. w auli dyskusja. Być może zabrakło na nią po prostu czasu. Odnośnie zaś kwestii nas interesującej należy poczytać za pewne zaniedbanie fakt, że $\mathrm{w}$ obydwu schematach ani jednym słowem nie wspomniano o przywilejach patriarchów wschodnich. Stąd też najusilniejsze życzenie Jussefa i w tym wypadku pozostało niespelnione. Trzeba było czekać niemal 100 lat, aby to, do czego tak usilnie dążył melchicki patriarcha na I Soborze Watykańskim, doczekało się pelnej realizacji $w$ uchwałach Vaticanum II, zwłaszcza w ogłoszonym przez Sobór 21 XI 1964 r. Dekrecie o Katolickich Kościołach Wschodnich (Decretum de Ecclesiis Orientalibus Catholicis) ${ }^{75}$.

72 IM a n s i, 53, 45-61.

73 Tak postapił np. bp obrządku chaldejskiego Hindi: "Quare quaeso heic distinctio inter episcopos latinos atque orientales? "Nonne omnes sunt catholici? Si auctoritas est necessaria episcopis ritus latini, quare non erit pariter necessaria episcopis ritus orientalis?" (tamże, 61).

74 Tamże, 897-914. - Wprawdzie jest tu jeszcze bardzo mocno podkreślona zależność wschodnich obrządków od papieża: „De omnimoda et independenti auctoritate, quae vi primatus in universam ecclesiam Romano pontifici in re liturgica (...) competit, ita ut quoties pro sua sapientia id expedire iudicaverit, ritus mutare libere possit, nullum dubium" (tamże, 903).

${ }_{75}$ AAS, 57/1965/76-89. Por. W. de Vries, Il Decreto Conciliare sulle Chiese Orientali Cattoliche, „La Civilità Cattolica”, 116/1965/108121; P. P a $\mathrm{ka}$ a, Dekret soborowy o katolickich Kościolach wschodnich, W: Zeszyty Naukowe KUL $9(1966)$ z. 3 63-72; Na temat uprawnień i przywilejów wschođnich patriarchów w świetle tego Dekretu por.: C. Pujol, Decretum Concilii Vaticani II ,Orientalium Ecclesiarum" (Textus et Commentarium), Romae 1970 s. 69-71; E. Przeko p, Patriarchowie wschodni $w$ świetle dekretu "O Katolickich Kościolach wschodnich", „Roczniki Teologiczno-Kanoniczne”, 18(1971) z. 5. s. .......... 


\section{RÉSUME}

\section{LES TENDANCES OECUMENIQUES DANS LES ENONCẼS DE REPRÉSENTANTS DES ÉGLISES ORIENTALES AU Ier CONCILE DF VATICAN}

Le présent article se propose d'étudier la participation de représentants des Églises catholiques orientales aux travaux du Vaticanum I. II vise avant tout à déceler l'esprit de l'oecuménisme dans les interventions des hiérarques orientaux pendant le Vaticanum I. D'ailleurs la seule présence de 78 Pères orientaux ayant le droit de voter, dut sans doute exercer une influence oecuménique en montrant qu'à côté du rite latin il y avait encore d'autres rites au sein de l'Eglise catholique. Les interventions de trois patriarches orientaux unis montrent à quel point la discussion consiliaire concerna des questions cecuméniques. Les deux premières inteventions, des patriarches chaldéen et melkite, portèrent une forte empreinte oecuménique, tandis que l'énoncé du patriarche arménien se plaça plutôt du côté de l'opposition.

Le patriarche chaldéen de Babylone, Joseph Audo préconisait le maintien de la discipline inchangée des Eglises orientales, surtout des privilèges des sièges patriarcaux. L'intervention du patrarche de l'Église. chaldéenne ne suscita cependant pas beaucoup d'intérêt de la part des. Pères.

L'intervention du patriarche melkite, Grégoire Ious sef d'Antioche trouva un accueil plus vif. Grégoire prit énergiquement parti pour les Églises orientales séparées. Il fit tout ce qu'il put pour que le Cencile ne prononçât pas d'anathème contre les adversaires de la primauté et de l'infaillibilité pontificales. Il soutint vigoureusement le principe du maintien de la discipline inchangée des Eglises orientales, surtout des la primauté, le patriarche d'Antioche crut pourtant que certaines formules du schéma de la constitution relative aux Grecs, étaient incompatibles avec l'esprit de l'union, surtout là où les Grecs sont appelés non seulement schismatiques, mais encore hérétiques. S'opposant aux anathèmes, le patriarche insistait sur le fait que pour l'unité chrétienne la. charité et le désir ardent de s'unir à Dieu importent davantage que les polémiques, les discussions et les définitions dogmatiques.

Le patriarche arménien de Cilicie, Pierre IX Has ou n adopta un point de vue opposé en soutenant que les papes ne sauraient affirmer l'autonomiae des Élises d'Orient sous peine de se priver eux-mêmes du pouvoir suprême inhérent à l'essence de la primauté, du pouvoir notamment de diriger ces Églises. Bien que le patriarche arménien se soit prononcé entièrement dans l'esprit de la définition ultérieure de la primaufé pontificale, il faut dire qu'une considération oecuménique des. frères séparés n'est quère visible dans son intervention.

Les discours des patriarches d'Orient suscitèrent, bien qu'à un degré différent, une réaction assez vive des évêques réunis, du rite oriental aussi bien que latin. Les évêques latins, suivant l'exemple des orientaux, abordèrent mainte fois des problèmes oecuméniques. En fin de compte, les interventions des évêques unis, surtout du patriarche I ous sef, audacieuses pour l'époque, ne trouvèrent pas d'accueil favorable au Concile: l'archevêque, de Trévise, Frédéric zinel1i, relateur de la Commission pour les Affaires de la Foi, exprima le plus nettement cette attitude réprobatrice en constatant officiellement que dans la constitution dogmatique Pastor aeternus il ne pouvait y avoir même de mention relativement aux privilèges des sièges patriarcaux d'Orient, vu que ces questions relèvent simplement de la discipline. En ce qui concerne l'anathème contre les adversaires de la primauté pontificale, Inelli 
précisa que les Grecs étaient hérétiques puisqu'ils refusent la promauté juridictionnelle de l'Evêque de Rome, basée sur le droit divin. Etant donné que l'attitude de Zinelli exprima en même temps la position de la Commission et de la majorité des Pères latins, l'espoir de voir une prise en considération, dans le texte de la constitution, des postulats oecuméniques formulés par les représentants orientaux, s'évanouit. II a fallu attendre presque cent ans jusqu'à ce que dans les délibérations et dans les décissions du Vaticanum II, les postulats du patriarche melkite Ioussef eussent été pleinement réalisés.. 